\title{
MENGUNGKAP REALITAS DENGAN PROYEK SENI SEBAGAI METODE PENCIPTAAN KARYA DALAM MEA
}

\author{
Octalyna Puspa Wardany \\ opuspad@gmail.com
}

\begin{abstract}
The implementation acceleration of ASEAN Economic Community from 2020 to be 2015 is not only impacted on economic and politic. It also brings the impact on the freedom of cultural flow. This situation then need the method and tool to creating arts which enable the artists and the actors in arts to works in other countries or places within ASEAN scope which material is the community reality as fusion form between social and cultural (in this term is arts) and also possible with other fields. Through this paper, the researcher would like to propose a method of creating artworks that is the art project which reveals the reality in community as an effort to contribute in advance and develop Indonesia arts world and unearth the arts in terms of ideas of working, creating process, and artworks. This research method is case study of Tentang Hutan Art Project of gerimisUngu Production by reference review, field research and empirical experience, observation, and interview. Based on this case, it found that (1) The Art Project is a method of creating artworks which based on currently reality in the community that is already examined using scientific research; (2) The Art Project is able to be implemented at any location, including MEA context and for any type of arts; (3) The Art Project is enable arts including their artworks become unity with the live; (4) The Art Project does not abandon the aesthetic values as the content of the artworks.
\end{abstract}

Keywords: Art Project, MEA, community reality, creating arts, aesthetic

\section{Pendahuluan}

Pembentukkan Komunitas ASEAN di tahun 2020 telah diputuskan dalam Declaration of ASEAN Concord II di Bali, Indonesia pada 7 Oktober 2003. Menyadari adanya peningkatan ketergantungan ekonomi negara-negara ASEAN baik dalam kawasan maupun dengan kawasan lain di dunia dan penekanan pentingnya memperkecil kesenjangan pembangunan, pemberlakukan Komunitas Ekonomi ASEAN atau Masyarakat Ekonomi ASEAN diakselerasi menjadi tahun 2015. Akselerasi pemberlakuan ini didasarkan pada hasil KTT ke-12 ASEAN di Cebu, Filipina pada 13 Januari 2007 yang ditandatangani oleh 10 negara ASEAN, yaitu: Brunei Darussalam, Kerajaan Kamboja, Republik Indonesia, Republik Rakyat Demokratik Lao, Malaysia, Uni Myanmar, Republik Filipina, Republik Singapura, Kerajaan Thailand, dan Republik Sosialis Viet Nam. Keputusan pembentukan KEA/MEA ini bertujuan mencapai tingkat dinamika ekonomi yang lebih tinggi, kemakmuran yang berkelanjutan, pertumbuhan yang merata dan pembangunan ASEAN yang terintegrasi (http://www.asean.org/archive/518710.pdf, bagian Declaration on the ASEAN Economic Community Blueprint ). Hal-hal penting dalam cetak biru Komunitas Ekonomi ASEAN, yaitu:

1. Republik Indonesia termasuk dalam 5 negara yang siap bersama Brunei Darussalam, Malaysia, Republik Singapura, Kerajaan Thailand. Hal ini ditunjukkan dengan tahun pemberlakukan pembebasan tarif bea masuk $(2007$ \& 
2012) dan hambatan non-tarif (2010) barang-barang intra ASEAN yang lebih cepat (http://www.asean.org/archive/5187-10.pdf, bagian A1, no. 13 dan 14).

2. Ada 3 pilar yang integral dalam pembentukan Komunitas ASEAN, yaitu: Komunitas Ekonomi ASEAN yang merupakan tujuan integrasi regional, Komunitas Keamanan ASEAN, dan Komunitas Sosial Budaya ASEAN (http://www.asean.org/archive/5187-10.pdf, bagian I, no. 2). Seni yang merupakan salah satu unsur kebudayaan turut menjadi tiang penting keberlangsungan dan kehidupan KEA.

3. Empat karakteristik utama KEA (http://www.asean.org/archive/5187-10.pdf, bagian II, no. 8): (a) pasar tunggal dan basis produksi, (b) kawasan ekonomi berdaya saing tinggi, (c) kawasan dengan pembangunan ekonomi merata, (d) kawasan yang terintegrasi penuh ke dalam ekonomi global.

4. Ada lima elemen utama dan dua komponen penting yang terlibat dalam pasar tunggal dan basis produksi (http://www.asean.org/archive/5187-10.pdf, bagian II.A, no. 9). Lima elemen utama tersebut adalah (i) Aliran bebas barang, (ii) Aliran bebas jasa, (iii) Aliran bebas investasi, (iv) Aliran modal yang lebih bebas, (v) Aliran bebas tenaga kerja terampil. Dua komponen penting adalah ${ }^{1}$ Sektor-sektor Integrasi Prioritas dan pangan, pertanian, kehutanan.

Kelima aliran bebas tersebut memberikan dampak pada kebebasan aliran kebudayaan pula, termasuk seni. Selain itu, terdapat identitas tambahan bagi 10 negara anggota ASEAN berupa identitas ASEAN itu sendiri selain identitas masyarakat negara masing-masing. Pembentukkan identitas ASEAN salah satunya juga didukung dengan aliran kebudayaan antar negara ASEAN.

Sementara, realitas yang berlangsung di masyarakat negara-negara ASEAN belumlah mengetahui perihal MEA beserta berbagai dampak yang terjadi. Masih ada kelompok-kelompok masyarakat yang bergulat pada persoalan kestabilan ekonomi, pengelolaan sumber daya, pensinergian kerja-kerja di wilayahnya dengan gerak langkah kemajuan di negaranya. Seni sebagai salah satu hasil kebudayaan manusia memiliki kemampuan untuk mengungkapkan hal-hal tersebut dari ranah lokal ke masyarakat yang lebih luas karena kelenturan bahasa yang digunakannya. Namun demikian, seni sering kali termandulkan oleh konsentrasi pada penciptaan seni itu sendiri meski kemungkinan untuk bekerja bersama bidang-bidang kebudayaan lainnya sangatlah memungkinkan.

Situasi ini membutuhkan metode/cara penciptaan seni yang memungkinkan seniman dan para pelaku seni berkarya di negara lain atau di tempat lain dalam lingkup ASEAN dengan materi berupa realitas masyarakatnya sebagai bentuk perpaduan antara bidang sosial dengan kebudayaan (dalam hal ini seni) dan juga tak menutup kemungkinan dengan bidang-bidang lainnya. Melalui makalah ini, penulis mengusulkan sebuah metode penciptaan karya seni yang dapat diterapkan dalam Komunitas Ekonomi ASEAN.

\footnotetext{
${ }^{1}$ Priority Integrity Sectors, seperti: transportasi, informasi, komunitasi, teknologi, HKI, dll.
} 


\section{Metode Penelitian}

Untuk dapat melihat kesesuaian proyek seni sebagai metode penciptaan karya seni yang dapat digunakan dalam mendukung aliran kebudayaan antar negara ASEAN, penelitian ini menggunakan teori seni riset atau Art Research oleh Andres Ramirez Gaviria. Seni riset atau Art Research adalah salah satu bentuk seni yang merupakan perkembangan seni kontemporer dengan menggabungkan seni dan penelitian.

Berdasarkan hasil penelitian Andres Ramirez Gaviria (Gaviria, 2008: 450, 479-482):

"Seni riset merupakan salah satu sistem perupaan informasi. Kelemahan seni riset ini bahwa perupaan informasi artistik kurang menekankan bentuk-bentuk estetik karena adanya kesempatan yang terberi untuk meninggalkan kemiripan dengan obyek-obyek seni atau pun memenuhi tujuan non-artistik lainnya. Jenis seni ini tidak umum, tapi khusus dalam hal bentuk dan tujuan, dan hasil-hasil atau implikasinya hanya dapat dipahami oleh komunitas-komunitas khusus sepenuhnya. Sebagai satu disiplin yang memerlukan evaluasi tepat untuk ditempatkan dalam praktik-praktik seni kontemporer, dasar kebenaran seni ini hanya melalui berbagai strategi dan metodologi yang dipahami orang tertentu, yaitu: orang yang menyusun seni riset saja. Demikian halnya dengan perupaan informasi artistik yang hanya dapat masuk akal bagi orang tertentu”.

Meski hasil penelitian Gaviria tentang sistem perupaan informasi memungkinkan sinergisitas seni dengan muatan realitas sosial kemasyarakatan yang up to date, Gaviria masih meragukan kekuatan estetik atas karya-karya seni yang dihasilkan oleh seni riset. Gaviria juga melihat bahwa komunikasi yang berlangsung atas jenis seni ini hanya dipahami oleh orang-orang tertentu dalam komunitas yang memiliki kesepemahaman atas informasi yang dirupakan. Hal ini sebenarnya bukan merupakan kelemahan yang bersifat final. Hal ini justru menjadi tantangan bagi para seniman yang mengimplementasikan jenis seni ini karena bagaimana pun karya seni dan seni tidaklah dapat dilepaskan dari estetika yang merupakan salah satu unsur inti dalam seni. Perihal strategi dan metodologi yang menurut Gaviria hanya dipahami orang tertentu juga belum bisa disebutkan sebagai simpulan akhir atas seni riset. Strategi dan metodologi merupakan cara dan alat yang justru memampukan jenis seni ini dapat dipahami secara luas. Strategi dan metodologi selalu dapat dikembangkan dan direvisi berkaitan dengan konteks lokasi, waktu, dan budaya masyarakat tempat seni riset diberlangsungkan. Pengembangan dan revisi tersebut justru memperkaya ragam strategi dan metodologi untuk penerapan seni riset yang dalam hal ini adalah proyek seni.

\section{Proyek Seni sebagai Metode Penciptaan Seni}

Proyek Seni Tentang Hutan merupakan sebuah kerja seni kolektif yang diselenggarakan gerimisUngu Production. Proyek ini berangkat dari penelitian seorang antropolog; Dwi Any Marsiyanti, S.Ant., M.A.; yang berjudul The Impact of Social Movement on The Socioeconomic Security, tahun 2011 di Desa Ngadisono, Kecamatan Kaliwiro, Wonosobo, Jawa Tengah. Proyek ini melibatkan 8 orang seniman, yaitu : 
Allatief, Dwi Joko Harianto, Ferial Afiff, Fitriana D.K., Harlen Kurniawan, Hiroshi Mehata, Isrol Triono, dan Seppa Darsono sebagai dokumentator audio-visual.

Perjalanan proses proyek seni ini secara keseluruhan membutuhkan waktu 4 tahun, sejak 2011 hingga 2014, yang meliputi: (1) Perancangan riset di tahun 2011; (2) Pelaksanaan riset di tahun 2012; (3) Perancangan proyek seni di tahun 2012; (4) Penggalangan dana tahun 2013; (5) Pelaksanaan proyek seni tahun 2013 - 2014.

Pelaksanaan proyek seni berlangsung selama 12 bulan dengan rangkaian kegiatan berupa:

1. Pendekatan dan perijinan ke lokasi proyek seni bulan Oktober 2013.

2. Observasi dan pemetaan lokasi untuk implementasi November 2014 - Januari 2014.

3. Diskusi pembacaan hasil riset oleh tim kerja proyek seni di bulan Januari 2014 yang melibatkan seniman, konseptor, peneliti, dokumentator, dan tim kerja produksi.

4. Pelaksanaan tinggal dalam lokasi proyek seni di bulan Februari - Mei 2014.

5. Diskusi Publik membagikan hasil tinggal dalam lokasi proyek seni Juni 2014.

6. Pembuatan karya Maret - Agustus 2014.

7. Presentasi karya seni rupa di Desa Ngadisono pada 16 Agustus 2014.

8. Pameran seni rupa 23 - 29 Agustus 2014.

9. Diskusi publik proyek seni 29 Agustus 2014.

10. Evaluasi dan pelaporan proyek seni September 2014.

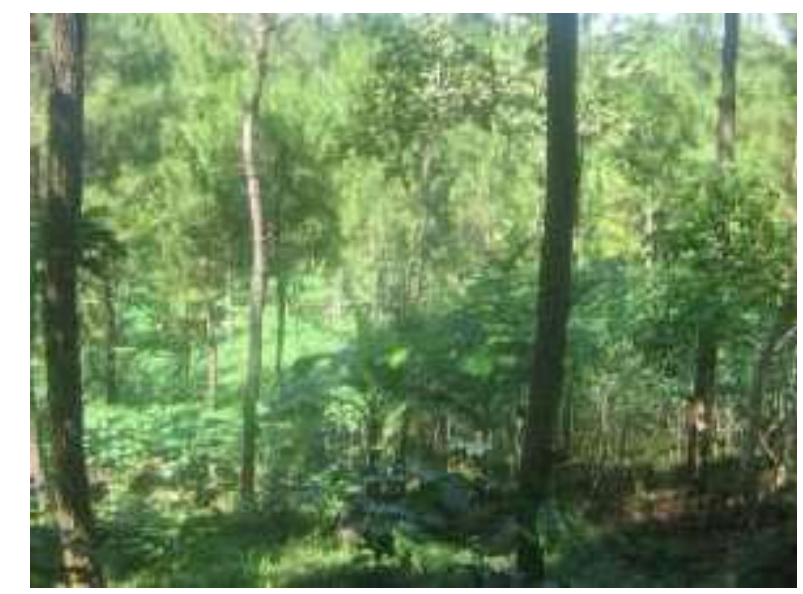

Gambar 1: Kawasan Hutan Desa Ngadisono, Wonosobo, Jateng Foto oleh Nanda Wirabaskara

Proyek seni ini dilatarbelakangi semangat pengelolaan hubungan dan kerja sama antara para seniman dan masyarakat dalam proses pembuatan karya seni. Yang menjadi sumber eksplorasi untuk penciptaan karya seni adalah masyarakat Desa Ngadisono, Kecamatan Kaliworo, Kabupaten Wonosobo, Jawa Tengah, Indonesia. Hal yang menarik dari masyarakat setempat adalah proses dan keberhasilan gerakan sosial dengan adanya kerja sama dengan pihak Perhutani dalam pengelolaan hutan negara sebagai sumber daya alam yang penting yang berlangsung sejak lebih dari 10 tahun yang lalu. 


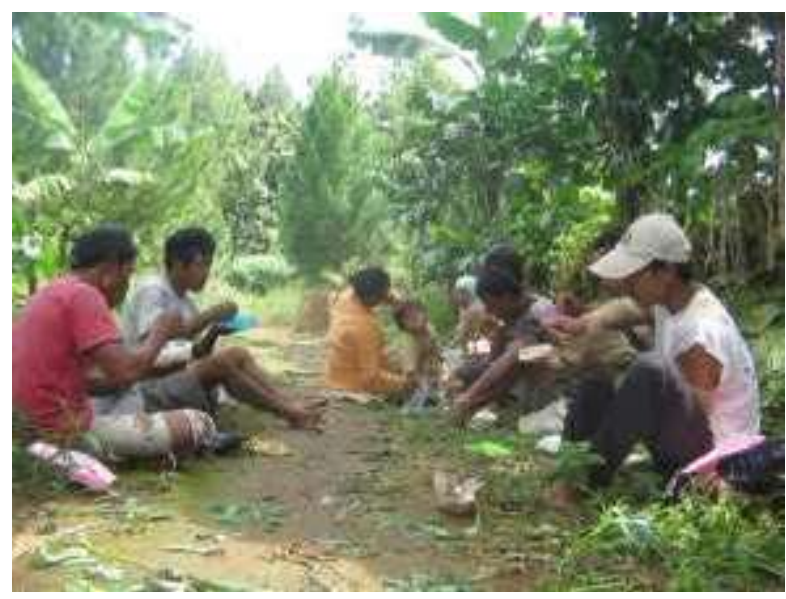

Gambar 2: Petani Beristirahat di Kawasan Hutan Desa Ngadisono, Wonosobo Foto oleh: Nanda Wirabaskara

Hasil penelitian antropologi sebagai pijakan awal bagi para seniman dalam melakukan proses eksplorasi penciptaan seni. Penelitian ini merupakan hal penting sebagai penyedia data yang akurat dan teruji secara ilmiah. Berdasarkan hasil penelitian, keberhasilan masyarakat Desa Ngadisono membuat kesepakatan dengan pihak Perhutani turut memberikan dampak berupa peningkatan kehidupan bidang sosio-ekonomi dan lingkungan. Keberhasilan tersebut merupakan satu hal yang layak diceritakan pada publik dengan media seni. Seni menjadi pilihan media ungkap karena adanya muatan estetika dalam karya, dan fleksibilitas pengungkapan yang cukup luas, serta hadirnya proses interpretasi dari fakta nyata menjadi karya seni.

Proyek seni ini bertujuan sebagai berikut :

1. Untuk melakukan proses eksplorasi dan penciptaan karya seni melalui hubungan dan kerjasama antara para seniman dengan sumber daya gagasan karya-karya seni secara langsung dan secara sadar, yaitu: masyarakat dan lingkungan, dengan memiliki konsep proyek seni yang berdasarkan pada penelitian dan metodologi proses seni yang mencukupi.

2. Untuk menempatkan seni sebagai media ekspresi yang mengandung muatan estetika dan sebagai media untuk menyampaikan situasi dan kondisi tertentu kepada publik. Dalam proyek seni ini, situasi dan kondisi tertentu tersebut adalah masyarakat Desa Ngadisono, Kecamatan Kaliworo, Kabupaten Wonosobo, Jawa Tengah, Indonesia.

3. Untuk melaksanakan proses pembelajaran bersama dengan melibatkan para seniman dan masyarakat serta lingkungan dalam proses penciptaan karya seni secara langsung dan secara sadar, juga pertemuan tim kerja proyek seni secara keseluruhan (seniman, peneliti, penulis, tim produksi, dan masyarakat) dalam pelaksanaan proyek seni ini. Dalam hal ini, proyek seni dan/atau perayaan seni adalah pekerjaan yang melibatkan banyak orang sebagai tim kerja yang memiliki fungsi tertentu yang saling berkaitan dan sama-sama penting serta memiliki posisi yang setara. 


\section{Temuan dan Pembahasan}

Di penghujung proyek seni, diselenggarakan pameran seni rupa dan diskusi publik di Jogja National Museum, Yogyakarta. Ada 18 karya dari 7 seniman yang dipajang dalam ruang terpisah berdasarkan seniman penciptanya Kedelapan belas karya seni tersebut terdiri atas:

1. Tiga instalasi.

Roar of Shin-Ku (Gambar 3) diciptakan Hiroshi Mehata tanpa menjejakan langkah di lokasi proyek seni. Ia melakukannya berdasarkan referensi, berupa: hasil penelitian Dwi Any Marsiyanti, S.Ant., M.A., dokumentasi foto dan video tim proyek seni selama dilokasi. Dari hasil diskusi dengan kurator proyek seni, keseluruhan data tersebut kemudian dielaborasikannya dengan penyerapannya tentang hutan di sebuah kuil di Tokyo, Jepang. Dalam instalasi yang memadukan benda-benda keseharian masyarakat Jepang (mangkok, bel, kipas, lampion, origami), videografi, dan musik electro; ia menyuguhkan spirit hutan yang menyatu dengan kehidupan manusia. Pada titik ini, ia mengemukakan bahwa hutan tak lagi berbatas material fisik. Hutan turut mempengaruhi jiwa manusia dan mengembangkan kepekaan manusia dalam hidup seirama dengan alam.

Intalasi Bukit Bentang (Gambar 4) oleh DJ Har atau Dwi Joko Harianto berkait dengan kesan yang tak pernah lepas darinya atas Bukit Bentang di lokasi proyek seni. Bukit itu menjadi saksi bisu ketika pengrusakan hutan berlangsung. Pohon-pohon yang ditanam dan dirawat para penduduk desa ditebang. Hutan yang dijaga masyarakat setempat dibabat dan dihancurkan. Para petani yang adalah penduduk setempat menangis dan gusar tanpa daya melihat kenyataan tersebut. Pada saat live in di lokasi, dari Bukit Bentang tampak nyata seluruh pemandangan hutan yang kini telah subur dengan tanaman pohon industri maupun tanaman bahan pangan masyarakat setempat. Kerusakan atau kelestarian alam begitu mudah dibolakbalikkan oleh manusia dan alam menjadi saksi yang seolah bisu.

Suburnya wilayah hutan yang kini terjadi tidak diraih dengan mudah. Ada perjuangan panjang yang melibatkan berbagai usaha disertai kesalahpahaman berbagai pihak yang terlibat (warga maupun pengelola hutan industri). Allatief dalam instalasi Jalan Panjang (Gambar 5) membeberkan kisah perjuangan masyarakat setempat untuk dapat mengelola hutan dalam kaitannya untuk kehidupan yang lebih baik bagi masyarakat setempat dan selaras dengan alam. 


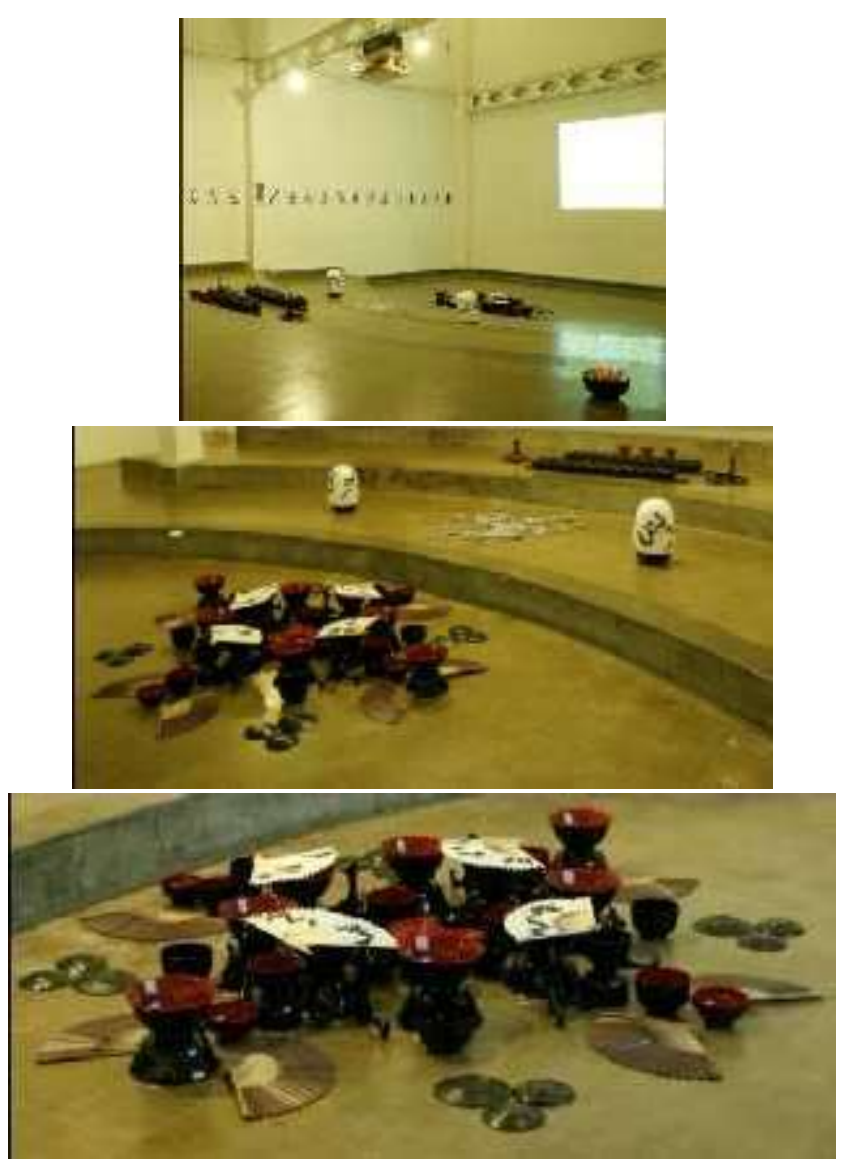

Gambar 3: Hiroshi Mehata; Roar of Shin-Ku

Musik dalam keping DVD, mangkok plastik Jepang, bel, kipas kertas Jepang, lampion Jepang, origami burung 100 unit; Instalasi; 2014

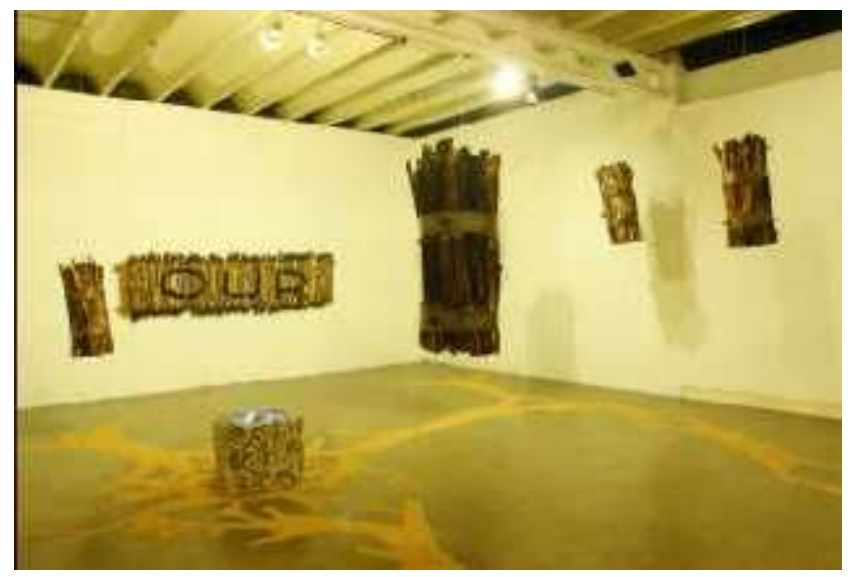

Gambar 4: DJ Har; Bukit Bentang

Kayu bakar, plat besi, serbuk gergaji, mur dan baut, 7 media variabel kayu bakar; Instalasi; 2014 


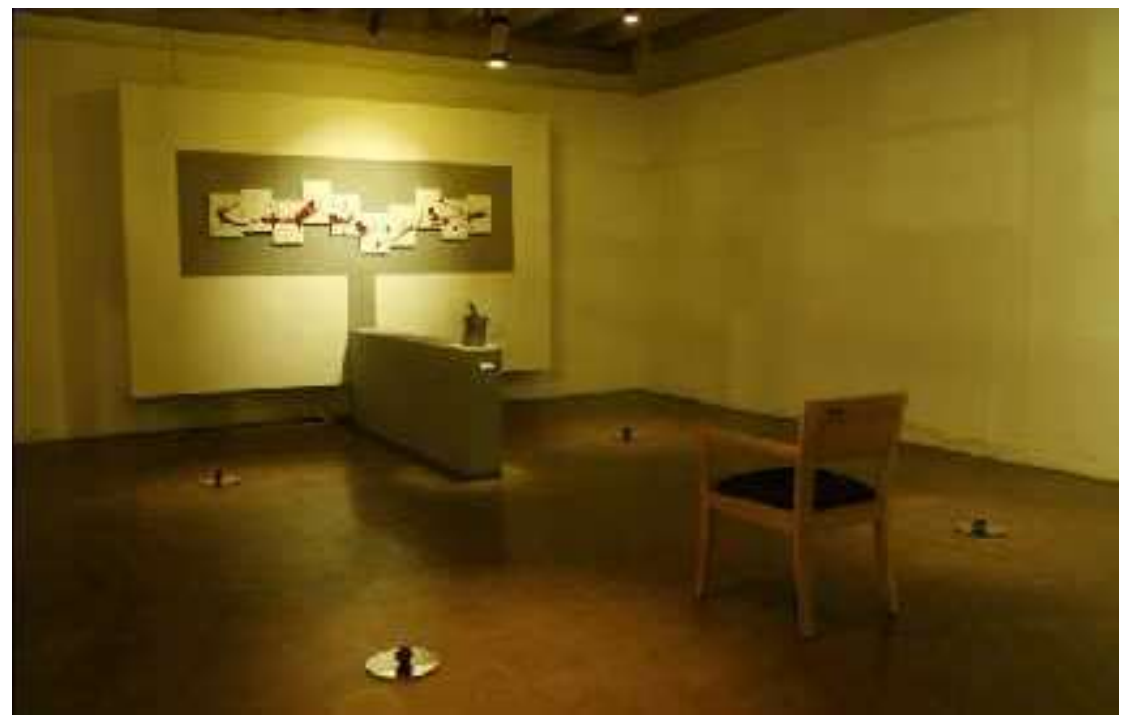

Gambar 5: Allatief; Jalan Panjang; Media Campuran; Instalasi; 2014

\section{Karya grafis}

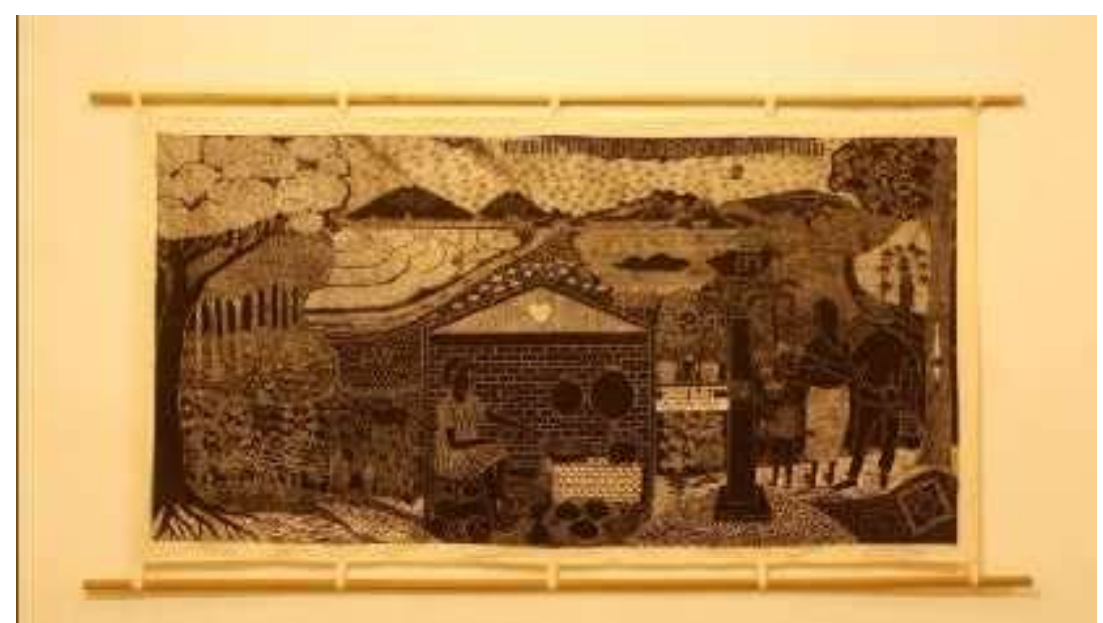

Gambar 6: Fitri D. K.; Berdiri di Atas Kedaulatan Pangan Sendiri

Cukil kayu di atas kain belacu dan kayu; 260cm x 140cm; 2014

Karya grafis berjudul Berdiri di Atas Kedaulatan Pangan Sendiri (Gambar 6) merupakan tangkapan Fitri D. K. atas keberhasilan Socioeconomic Security yang berlangsung di lokasi proyek seni dengan menyuguhkan pemandangan dan aktivitas keseharian masyarakat setempat. 


\section{Video Art}
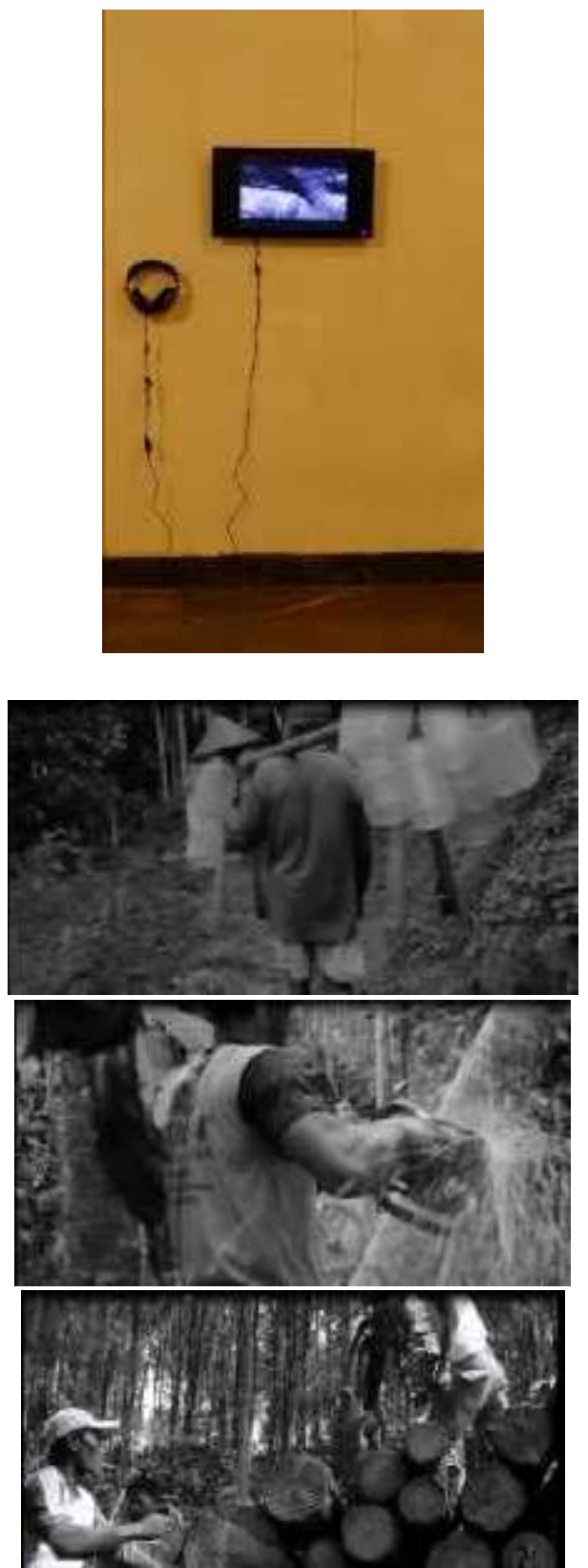

Gambar 7: Isrol Medialegal; Forest Therapy

(gambar video: Penderes Nira, Petani Albasia, dan Petani Pinus)

Video Art; 3 menit 52 detik; 2014

Video art Isrol Medialegal menceritakan aktivitas masyarakat di lokasi proyek seni dalam kaitannya dengan hutan. Ada petani yang setiap hari menderes getah pohon nira untuk dimasak menjadi gula aren yang lezat. Ada petani pohon albasia sedang menebang pohon-pohon di hutan rakyat yang rusak terkena gulma. Ada aktivitas menebang pohonpohon di hutan industri oleh para petani pinus untuk dijadikan bahan plywood atau kertas yang juga berguna. 


\section{Dua Foto Performans}

Dua foto performans art Ferial Afiff menyuguhkan kontrdiksi yang ia tangkap dari pengelolaan hutan rakyat dan hutan industri. Dari segi kesuburan alam, hutan industri dipenuhi dengan pohon-pohon pinus yang subur dan tanaman pangan rakyat di sela-sela pohon. Hutan tersebut tampak hijau dan lestari. Sementara, salah satu lokasi hutan rakyat justru tak tampak pepohonan rindang. Lokasi hutan rakyat tersebut merupakan lokasi perbukitan yang rawan longsor dan pada saat tim proyek seni tinggal di lokasi, longsong baru saja terjadi di lokasi tersebut. Melalui dua foto performans ini, Ferial mempertanyakan perihal pengelolaan hutan yang berlangsung dalam kaitannya dengan menjaga kelestarian alam berdasarkan tangkapan pancaindera.

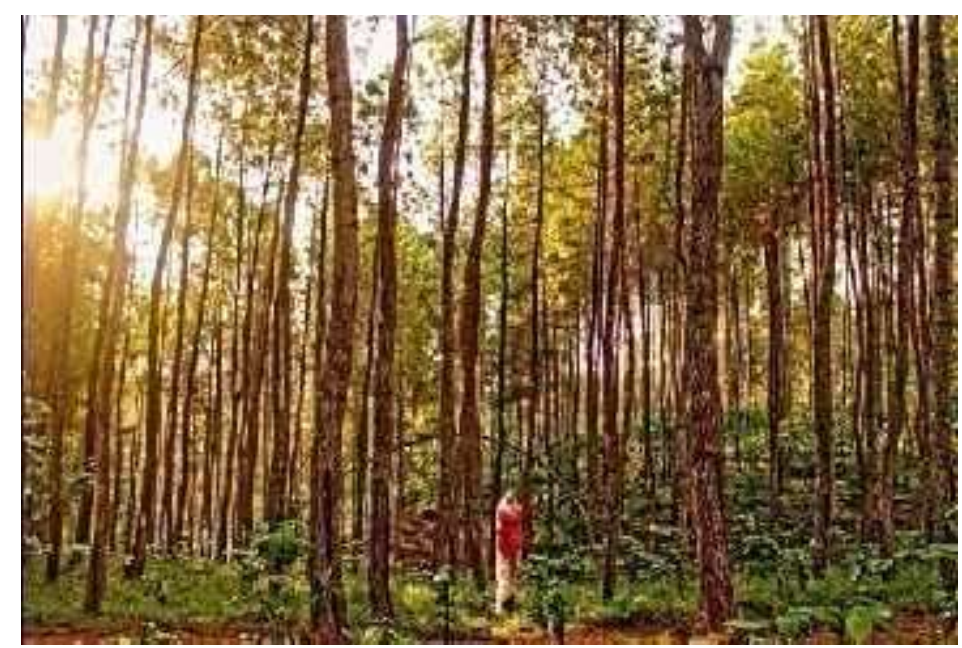

Gambar 8: Ferial Afiff; Melanomata A;

C-print Alumunium D-bond; 108cm X 72cm; 3ed \& 1ap; 2014

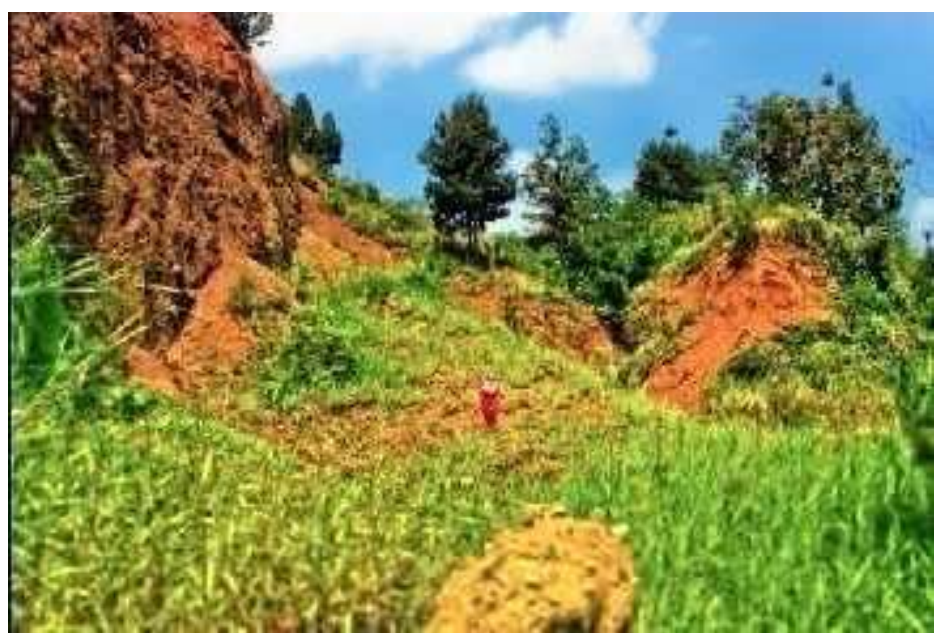

Gambar 9: Ferial Afiff; Melanomata B;

C-print Alumunium D-bond; 108cm X 72cm; 3ed \& 1ap; 2014 


\section{Dua Video Performans}
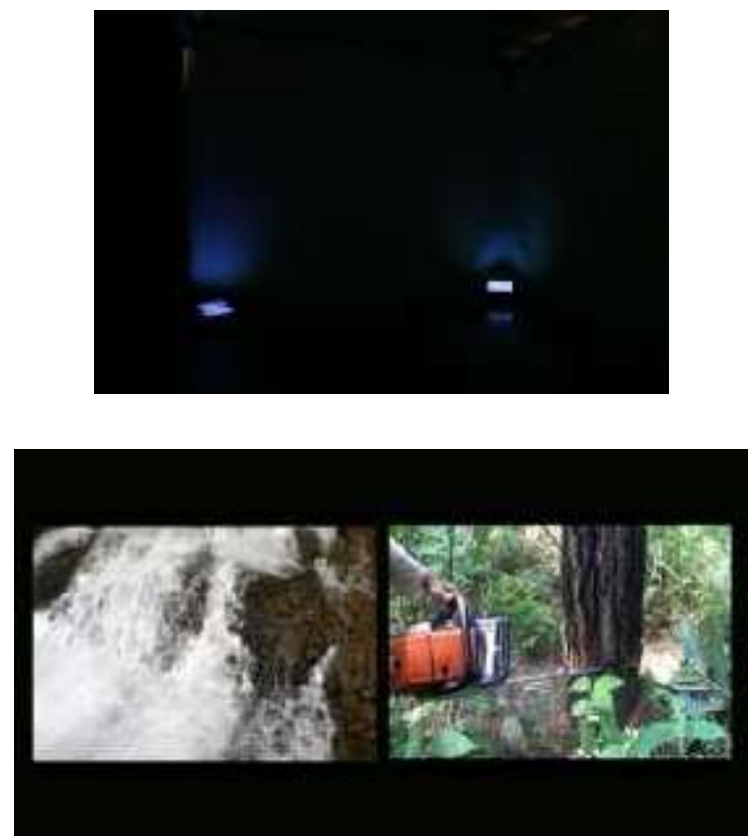

Gambar 10: Ferial Afiff; Melanomata $C$;

Video 2 panel; 1 menit 19 detik, mp4; 10ed \& 1ap; 2014

Video performance art Ferial Afiff mengungkapkan penyakit yang merusak aliran air yang menjadi kebutuhan pokok hidup dan diproduksi oleh alam. Berangkat dari peristiwa kekeringan yang pernah berlangsung di lokasi saat hutan belum lestari, Ferial menyajikan pemikiran masyarakat setempat bahwa penebangan pohon yang tak terkendali laksana tumor yang memberikan noda hitam di kulit

(http://www.thefreedictionary.com/melanomata).

\section{Lukisan}

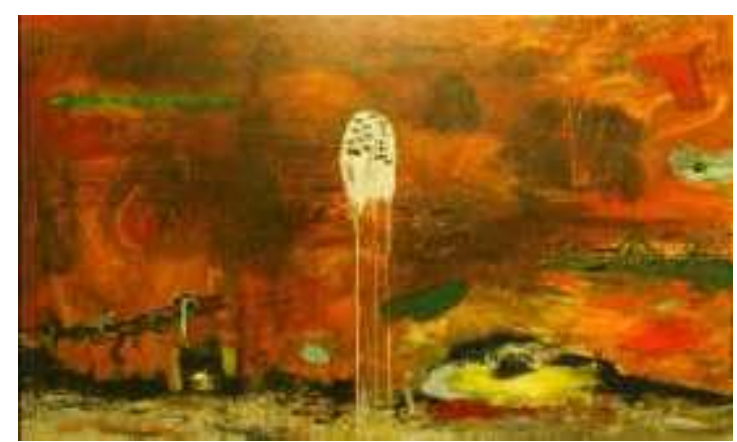

Gambar 11: Harlen Kurniawan; Acrylic on canvas; 120cm x 200cm; 2014 
Lukisan Harlen Kurniawan menyuguhkan tentang gejolak yang berlangsung saat pengrusakan hutan berlangsung pada saat penebangan hutan besar-besaran terjadi di lokasi proyek seni. Harlen yang tak dapat mengikuti proses live in, mengungkapkan cerapannya dalam lukisan berdasarkan informasi dan data referensi seperti Hiroshi Mehata.

\section{Satu Karya Kaligrafi Jepang}

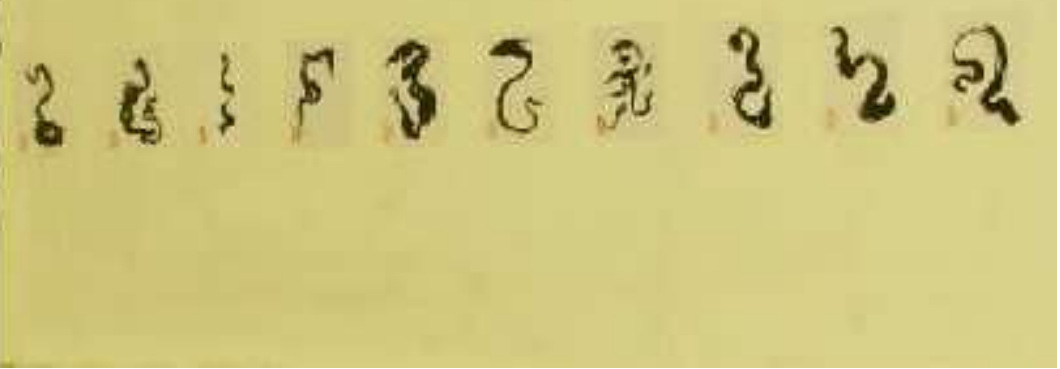

Gambar 12: Hiroshi Mehata; Shadow Noun Hutan; Tinta Cina di tas kertas; 88 unit; @A4; Kaligrafi Jepang; 2014

Cerapan Hiroshi atas hutan disuguhkan pula dalam kaligrafi Jepang yang mengungkapkan bayangan hutan yang menyatu dalam kehidupan manusia. Spirit hutan yang muncul dalam gerak langkah keseharian manusia hingga mengada dalam berbagai simbol dan ungkapan yang dihasilkan manusia.

\section{Satu Karya Seni Obyek Temuan}

Cermin Jiwa oleh Allatief menyuguhkan kecintaan masyarakat petani di lokasi proyek seni terhadap alam sehingga mereka terus berupaya untuk dapat menanam pohon, menjaga lokasi hutan, turut serta mengelola hutan di wilayah tinggal mereka. Upaya yang membutuhkan kegigihan dan keteguhan besi.

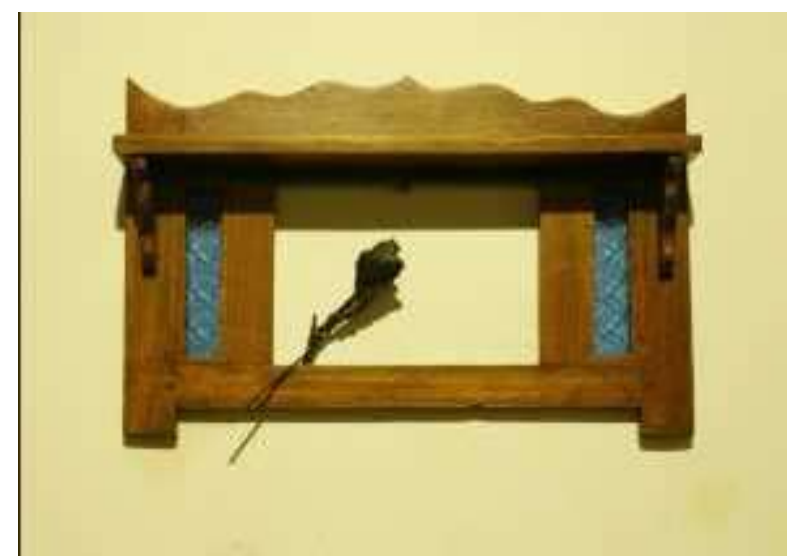

Gambar 13: Allatief; Cermin Jiwa; Kayu, gelas, besi; Obyek Temuan; 2014 
Selain karya seni, juga dipajang peta Dusun Ngadisono dan Desa Kaliwiro dengan teknik cetak digital di dinding kanan dan kiri setelah pintu masuk, 5 batok kelapa berisi getah pinus di lorong gedung pameran. Peta tersebut sebagai penghantar para pemirsa yang hendak memasuki ruang pameran dalam upaya menghadirkan kesadaran bahwa mereka akan dibawa ke lokasi tempat proyek seni ini berlangsung. Kelima batok kelapa berisi getah pinus yang dipasang berjajar di lorong antar kamar-kamar pameran menjadi pengingat para pemirsa yang lalu-lalang dari satu ruang ke ruang berikutnya tentang muasal berlangsungnya cerita pengelolaan hutan bersama yang diangkat dalam proyek seni ini.

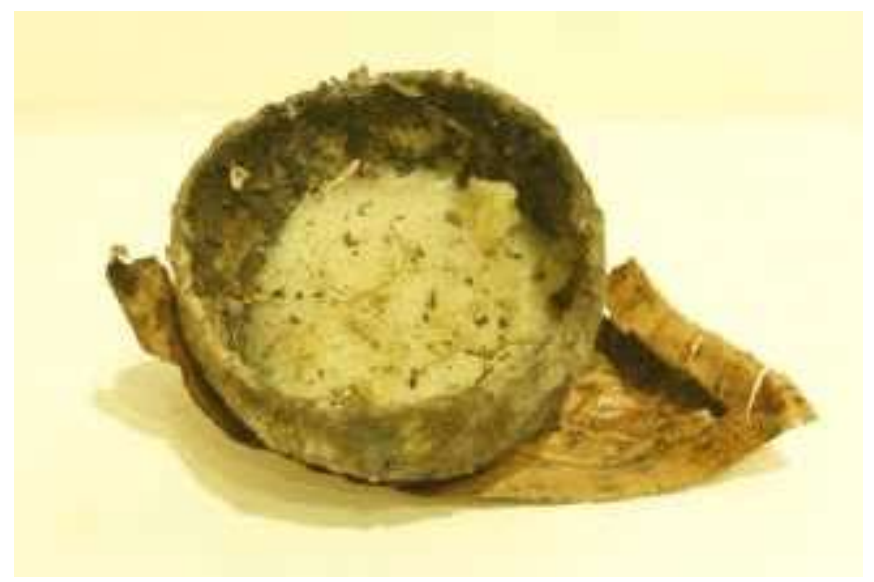

Gambar 14: Artefak Hutan Ngadisono; getah pinus dalam batok kelapa

Upaya menyuguhkan narasi perjalanan proses dan berbagai kegiatan yang dilakukan proyek seni ini dengan menghadirkan satu ruangan berisi dokumentasi foto dan video oleh Seppa Darsono, juga hasil penelitian Dwi Any Marsiyanti, S.Ant., M.A. Secara garis besar; dokumentasi foto (Gambar 15 dan 16) berisi aktivitas yang berlangsung dalam proses proyek seni ini, aktivitas masyarakat, berbagai tumbuhan dan hasil bumi, hutan industri dan produksi di lokasi. Sementara, dokumentasi video berisi perjalanan kedelapan seniman selama di lokasi.

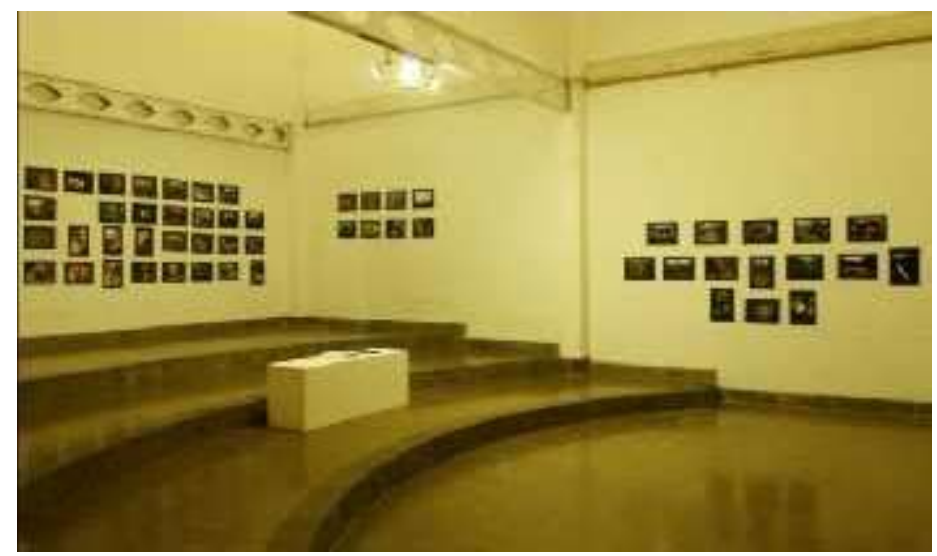

Gambar 15: Seppa Darsono (Gerimisungu commision artworks); Dokumentasi Foto Proyek Seni; 2014 


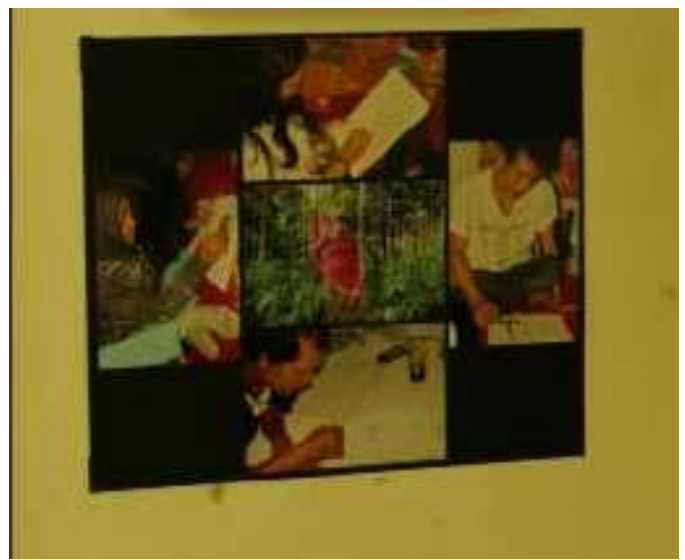

Gambar 16: Seppa Darsono (Gerimisungu commision artworks); Dokumentasi Foto Proyek Seni; 2014

Jika dilihat dari pemaparan Gaviria, Proyek Seni 'Tentang Hutan' ini termasuk dalam kategori seni riset karena adanya penggabungan antara penelitian dan seni. Namun demikian, pembuatan proyek seni yang terhitung sejak tahun 2011, sebenarnya, tidak mengacu pada penelitian Gaviria yang diterbitkan pada tahun 2008 tersebut walau waktu perancangannya 3 tahun setelah hasilnya diterbitkan.

Pelaksanaan proyek seni ini sendiri dilandasi dengan penelitian; baik ilmiah maupun non-ilmiah; berupa:

1. Perolehan informasi tentang keberhasilan warga Desa Ngadisono bekerja sama dengan Perhutani dalam mengelola hutan negara, dampak kerja sama tersebut bagi peningkatan sosio-ekonomi warga desa dan jaminan keamanan wilayah hutan dengan penelitian kualitatif yang teruji secara ilmiah.

2. Pengayaan referensi visual dan penguatan informasi oleh para seniman dan tim kerja proyek seni melalui proses tinggal di dalam lokasi.

3. Pengayaan informasi dengan memberlangsungkan diskusi baik di tingkatan internal tim kerja proyek seni, termasuk para seniman, maupun di tingkatan umum melalui diskusi berbagi hasil temuan paska proses tinggal dalam lokasi dan diskusi publik proyek seni di akhir periode pameran.

4. Ada proses konfirmasi dan cross check melalui presentasi karya seni di lokasi; Desa Ngadisono.

5. Dokumentasi keseluruhan proses; tertulis, foto, dan audio visual (video).

6. Pertanggungjawaban proyek seni secara keseluruhan pada publik melalui pameran seni rupa, diskusi publik, penerbitan katalog, dan pelaporan pada publik melalui pengiriman katalog ke berbagai pihak yang berkepentingan dalam wahana seni; lembaga-lembaga dan para aktor seni.

Proyek seni ini juga mengandung perupaan informasi, yaitu: dengan menempatkan seni sebagai media untuk menyampaikan situasi dan kondisi Desa Ngadisono tentang keberhasilan pengelolaan hutan setempat kepada publik. Hal ini tercantum dalam tujuan penyelenggaraan proyek seni ini. Situasi dan kondisi dalam hal ini merupakan informasi 
yang hendak disampaikan melalui karya seni rupa. Dengan kata lain, terjadi perupaan informasi di dalam proyek seni ini yang merupakan sistem dalam seni riset.

Yang berbeda dalam proyek seni ini adalah estetika tetap menjadi lokus perhatian penting. Hal tersebut tampak dalam tujuan proyek yang menyebutkan bahwa estetika sebagai kandungan/muatan dalam karya-karya seni dan adanya proses eksplorasi penciptaan yang diberlangsungkan. Penerapan estetika dan proses kreatif seni tampak dalam hal-hal sebagai berikut:

1. Pemilihan para seniman yang terlibat; ada seniman performans, pelukis, penggrafis, pemusik, seniman media rekam, penulis.

2. Proses penciptaan karya seni yang tidak hanya di lokasi, tetapi juga di studio dengan pertimbangan ketersediaan jarak; ruang dan waktu; yang cukup bagi para seniman mengenai berbagai informasi dan referensi lokasi proyek seni.

3. Ada proses kuratorial, dalam hal pemilahan dan pemilihan, atas karya-karya seni yang dibuat melalui proses bertukar pikiran dan perbincangan yang membahas konsep, perwujudan karya secara visual, metode pengayaan referensi, bahan dan teknik yang diperlukan.

4. Ada penataan letak pemajangan karya seni yang mempertimbangkan wujud visual karya, kesatuan konsep dan nafas dari masing-masing karya seni, masing-masing seniman, dan kaitannya dengan proyek seni ini secara keseluruhan.

5. Ada kritik seni yang diberlangsungkan melalui presentasi karya di lokasi proyek seni, pameran seni ruang seni, dan evaluasi akhir.

6. Perwujudan/penciptaan karya seni oleh masing-masing seniman pun dijiwai oleh semangat seni dengan konsep estetika, berupa penempatan hasil riset, berbagai data, dan referensi lokasi sebagai landasan informasi yang diinterpretasikan oleh masingmasing seniman dan diwujudkan dalam karya-karya seni.

7. Ada kebebasan dan eksplorasi seni bagi masing-masing seniman yang terlibat untuk mengolah dan menginterpretasikan berbagai referensi mengenai lokasi dan data proyek seni tersebut.

Proyek seni ini mempertimbangkan pula akibat dan dampak yang mungkin terjadi dari proyek seni ini. Hal ini dipaparkan dalam tujuan berupa :

“... melaksanakan proses pembelajaran bersama dengan melibatkan para seniman dan masyarakat serta lingkungan dalam proses penciptaan karya seni secara langsung dan secara sadar, juga pertemuan tim kerja proyek seni secara keseluruhan (seniman, peneliti, penulis, tim produksi, dan masyarakat) dalam pelaksanaan proyek seni ini. Dalam hal ini, proyek seni dan/atau perayaan seni adalah pekerjaan yang melibatkan banyak orang sebagai tim kerja yang memiliki fungsi tertentu yang saling berkaitan dan sama-sama penting serta memiliki posisi yang setara".

Akibat dan dampak ini yang menjadi pertimbangan tersebut juga dinyatakan secara langsung oleh Bpk. Manzur sebagai perwakilan warga Desa Ngadisono dalam diskusi publik proyek seni dan pengamatan paska proyek seni ini rampung dilaksanakan. Akibat dari penyelenggaraan proyek seni adalah: 
1. Terjadi pertukaran pengetahuan mengenai seni bahwa kerja-kerja kesenian bukanlah melulu kerja di dalam studio dan ruang tertutup, tetapi juga memerlukan penelitian dan melibatkan proses turun ke lapangan.

2. Terjadi transfer pengetahuan pada warga setempat dalam mengenali benda-benda seni dan memiliki nilai sejarah di lokasi yang selama ini tidak diperhatikan dan perlu dirawat dengan baik.

3. Para seniman proyek seni mengetahui realitas kehidupan masyarakat di sekitar kawasan hutan negara secara langsung.

4. Para seniman proyek seni dapat menyebarkan informasi tentang pengelolaan hutan rakyat dan negara kepada publik luas melalui karya seni.

5. Para seniman proyek seni memperoleh pengetahuan tentang hutan, lingkungan dan kehidupan masyarakat di kawasan hutan negara.

6. Pemanfaatan Balai Desa Ngadisono sebagai lokasi pemajangan karya-karya seni menghadirkan pengetahuan bagi warga bahwa presentasi seni bukanlah merupakan hal yang eksklusif dan di lokasi-lokasi khusus.

7. Penyajian pertunjukkan Wayang Golek di malam terakhir proses tim kerja proyek seni tinggal di Desa Ngadisono menumbuhkan rasa percaya diri dan nilai apresiasi bagi kelompok tersebut yang sebelumnya mengalami kekosongan aktivitas berkesenian.

Sementara, dampak dari proyek seni sebagai berikut :

1. Publik mendapatkan suguhan karya seni berbasis realitas kehidupan masyarakat dengan persoalan yang nyata dan sungguh-sungguh terjadi.

2. Publik mendapatkan pengetahuan mengenai realitas kehidupan warga di kawasan hutan negara dan pengelolaan hutan yang merupakan paru-paru dunia.

3. Persoalan hutan dan lingkungan hidup manusia tidak lagi menjadi masalah pemerintah dan warga di sekitar kawasan hutan negara, tetapi menjadi perhatian dan kepedulian bersama.

4. Para seniman memperoleh nilai-nilai kehidupan dari warga di sekitar kawasan hutan yang berikatan dengan tanah dan hutan. Lebih lanjut, hakiki nilai-nilai tersebut dapat diterapkan dalam kehidupan di mana pun.

5. Warga Desa Ngadisono bersedia melakukan perawatan dan pelestarian benda-benda seni dan bersejarah. Contohnya: pembatalan penghancuran rumah mandor pada masa kolonial yang masih tersisa, kesediaan merawat patung batu Nini Gendhong di kawasan hutan negara.

6. Muncul semangat dan keinginan untuk menghidupkan kembali kesenian Wayang Golek Desa Ngadisono yang telah lama mati suri karena berbagai persoalan internal dari pertemuan antara para seniman dan pekerja seni Yogyakarta yang diwakili tim kerja proyek seni dengan kelompok seni Wayang Golek.

7. Ada keberlanjutan kerja sama antara warga setempat para seniman dalam proyek seni meskipun pelaksanaannya telah selesai yang dilandasi semangat kekeluargaan dan silahturahmi. 
Catatan yang perlu diperhatikan atas proyek seni ini adalah waktu pelaksanaan yang panjang. Durasi proses secara keseluruhan selama 4 tahun tentunya membutuhkan pembiayaan, energi, pemikiran yang tidak sedikit. Durasi 1 tahun untuk pelaksanaan proyek seni juga membutuhkan komitmen, daya tahan, ketangguhan, dan tanggung jawab yang besar dari masing-masing orang di dalam tim proyek seni. Di sisi lain, kebutuhan waktu yang besar untuk pelaksanaan proyek seni ini sangatlah sulit diterapkan mengingat kebudayaan kini yang berorientasi pada perolehan hasil secara cepat dan singkat. Perlulah ditemukan metode dan cara yang lebih baik, tepat, ringkas, efektif, dan efisien tanpa meninggalkan kualitas keluaran proyek seni, muatan estetika, dan proses kreatif seni.

Sebagai sebuah upaya mengembangkan dan mengeksplorasi lebih lanjut bidang seni riset yang merupakan salah satu jenis seni kontemporer ini, proyek seni dapat diterapkan di negara-negara ASEAN. Keunggulan sumber daya baik lingkungan/alam yang tersedia, kondisi sosial-politik-ekonomi, tradisi yang masih berlangsung dan dijaga, sumber daya manusia dengan nilai-nilai budaya yang hidup selaras dengan alam, situasi peralihan dan carut-marut yang ditimbulkan untuk menjadi negara dan masyarakat maju merupakan sumber daya yang dimiliki negara-negara ASEAN dan menjadi bahan berharga untuk disuguhkan dan diejawantahkan menjadi karya seni.

Karya seni sebagai bentuk penyajian realitas merupakan sebuah pilihan karena mengandung nilai estetik sehingga dapat menghadirkan makna beragam. Keberagaman makna tersebut membuat karya seni dapat terus hidup dan menjadi media komunikasi atau penyampaian informasi pada publik yang majemuk. Selain itu, karya seni juga memiliki kelenturan dalam pengungkapan realitas karena adanya interpretasi yang melibatkan daya analisis dan olah rasa.

Penelitian ilmiah tetaplah perlu dilakukan agar validitas informasi yang diperoleh dan selanjutnya disampaikan melalui karya seni benar-benar teruji, juga menjadi titik tolak para seniman dalam mengumpulkan data berupa fakta di lapangan untuk pembuatan karya seni. Penerapan penelitian ilmiah dan pengumpulan referensi (oleh seniman) memberikan manfaat karena data yang diperoleh masing-masing pihak dapat saling dicross check yang tentunya memperkuat hasil penelitian dan karya seni yang diciptakan.

Proyek seni sebagai sebuah metode pembuatan karya seni dapat diterapkan pada jenis seni apa pun; seni rupa, pertunjukkan, media rekam, dan lain-lain. Kebebasan seniman mengekspresikan realitas dalam karya seni secara tidak langsung menghadirkan tantangan untuk menyajikan bentuk-bentuk ungkapan yang sesuai dengan kedirian seniman tersebut yang tak menutup kemungkinan dapat memunculkan bentuk ungkap seni yang baru.

Kebebasan berekspresi tersebut -sebenarnya- dimulai sejak seniman melihat secara langsung realitas dengan tinggal di dalam lokasi. Seniman tak hanya memperoleh data hasil penelitian dan referensi visual, tetapi juga memperoleh referensi pengalaman dan referensi emosi dengan tinggal di dalam lokasi. Tak menutup kemungkinan, seniman memiliki pemahaman dan cara pandang yang berbeda dari masyarakat setempat. Dalam kasus Proyek Seni Tentang Hutan, cara pandang seniman tentang pengelolaan hutan sangatlah beragam dan ada juga yang berbeda dengan masyarakat setempat.

Dalam penerapan KEA, pelaksanaan proyek seni sangatlah dimungkinkan dengan berbagai kemudahan yang tersedia dari lima aliran bebas sebagaimana dipaparkan di 
bagian awal makalah ini. Sebagai contoh : seniman dari Indonesia dapat melakukan proyek seni di negara Thailand atau sebaliknya. Tak menutup kemungkinan beberapa seniman dari negara-negara ASEAN berkolaborasi dan melakukan proyek seni di satu atau beberapa negara.

Dengan metode pembuatan karya seni semacam ini, akan ada banyak sudut pandang dan pemaknaan melihat suatu realitas yang justru menjadi suatu pengayaan dalam memahami realitas tersebut baik oleh masyarakat tempat lokasi proyek seni, para seniman, dan publik penikmat karya seni. Dalam hal ini, cakrawala pengetahuan dan wawasan tentang realitas yang berlangsung dalam KEA diungkapkan dan dapat menjadi bahan refleksi untuk menelaah perkembangan KEA secara nyata.

Penerapan proyek seni dalam lingkup KEA memberlangsungkan proses pertukaran kebudayaan. Dalam tim proyek seni yang melibatkan orang-orang dari berbagai negara ASEAN, akan terjadi pengenalan kebiasaan dan cara pandang hidup berbeda dari budaya lain. Di lokasi proyek seni juga terjadi pengenalan adat-istiadat dan pola pikir lain baik antara tim proyek seni terhadap masyarakat setempat maupun sebaliknya. Ketika karya seni dihadirkan pada publik, selain mengapresiasi karya seni, publik juga akan memperoleh pengetahuan akan realitas lain dengan kebudayaan yang berbeda. Dengan demikian, proyek seni ini memberikan pemahaman akan budaya lain dan menjadi ruang bagi pertukaran kebudayaan.

\section{Kesimpulan}

Proyek seni dapat menjadi satu pilihan metode untuk memunculkan identitas ASEAN dan memperkuat salah satu pilar KEA ini. Kelebihan penerapan metode ini antara lain:

1. Realitas sosial sebagai material penciptaan karya seni lebih banyak dan beragam.

2. Sudut pandang atas suatu realitas sosial tak melulu dari masyarakat yang tinggal dalam realitas tersebut dengan melibatkan seniman dari negara yang berbeda dengan masyarakat yang menjadi subyek proyek seni dengan adanya aliran bebas manusia yang dalam hal ini adalah para seniman dan pelaku seni ASEAN.

3. Penikmat karya seni lebih luas dan beragam (lingkup ASEAN) tidak lagi hanya di lingkup satu negara tempat penyelenggaraan proyek seni.

4. Informasi yang termuat dalam karya seni hasil proyek seni dapat menjangkau publik yang lebih luas dengan berbagai keterbukaan ASEAN.

5. Terjadi pertukaran pengetahuan dan kebudayaan antar negara ASEAN melalui seni.

Ada pun tantangan dalam penerapan metode ini adalah

1. Bahasa yang berbeda jika para seniman dan peneliti yang terlibat bukan berasal dari negara tempat lokasi proyek seni. Namun demikian, hal ini dapatlah diminimalisir dengan karakteristik peneliti (ilmu sosial; antropologi) dan seniman yang sebagian besar terbuka pada segala perbedaan dengan kesediaan memahami ekspresi melalui bahasa non-verbal. 
2. Perbedaan pengelolaan, atmosfer, dan dukungan berkesenian di negara tempat lokasi proyek seni berada. Hal ini membutuhkan waktu adaptasi yang tidak cepat sehingga proses proyek seni bisa menjadi lebih lama.

Proyek seni dalam keberadaan Komunitas/Masyarakat Ekonomi ASEAN merupakan satu metode penciptaan karya seni yang sangat mungkin diterapkan dengan adanya berbagai kemudahan dan kebebasan dalam penerapan KEA. Proyek seni yang memuat penelitian ilmiah sebagai salah satu metode perolehan referensi bertepatan dengan salah satu agenda KEA yang termaktub dalam ASEAN Economic Community Blueprint bagian A5, Pasal 34, ayat iii, yaitu: "Streghten the research capabilities of each ASEAN Member Country..." Tak menutup kemungkinan, akan dihasilkan bentuk-bentuk seni baru ASEAN dari pelaksanaan proyek seni ini karena ruang kebebasan berekspresi bagi para seniman yang luas dengan dukungan referensi yang kuat dan kolaborasi para seniman dengan masyarakat secara langsung. Lebih lanjut, hal ini dapat pula membentuk identitas masyarakat ASEAN sebagai satu Komunitas/Masyarakat Ekonomi ASEAN.

\section{KEPUSTAKAAN}

Gaviria, Andres Ramirez (2008), When is Information Visualization Art? Determining the Critical Criteria, Jurnal Leonardo, Vol. 41, No. 5 (2008), pp. 479-482, 450, The MIT Press, diunduh tanggal 8 Juli 2014.

Marsiyanti, Dwi Any (2012), The Impact of Social Movement on the Socioeconomic Security of Peasants in Indonesia, Hasil Penelitian.

Sternberg, Robert J. Dan Todd I. Lubart (1996), The Concept of Creativity: Prospects and Paradigms dalam Handbook of Creativity, 1999, Cambridge University Press, United Kingdom.

Proyek Seni 'Tentang Hutan' (2014), proposal, katalog, pameran, diskusi publik, Yogyakarta: Gerimisungu Production.

ASEAN Economic Community Blueprint (Januari 2008), Jakarta: ASEAN Secretariat; AEC Blueprint: http://www.asean.org/archive/5187-10.pdf diunduh tanggal 25 Mei 2015.

Baskoro, Arya, Peluang, Tantangan, dan Risiko Bagi Indonesia Dengan Adanya Masyarakat Ekonomi ASEAN, http://crmsIndonesia.org/node/624 diakses tanggal 25 Mei 2015.

Berita Indonesia, 27 Agustus 2014, Apa yang harus Anda ketahui tentang Masyarakat Ekonomi ASEAN, http://www.bbc.co.uk/Indonesia/berita_Indonesia/2014/08/140826_pasar_tenaga_kerja_aec diakses tanggal 25 Mei 2015.

Kompas, 28 April 2015, Wapres: Masyarakat Ekonomi ASEAN 2016 Untungkan Indonesia, http://nasional.kompas.com/read/2015/04/28/02562181/Wapres.Masyarakat.Ekonomi.ASEA N.2016.Untungkan.Indonesia diakses tanggal 25 Mei 2015.

Tribun News, 13 Mei 2015, MEA Perlu Diwaspadai Agar Indonesia Tak Jadi Sasaran Pasar, http://www.tribunnews.com/bisnis/2015/05/13/mea-perlu-diwaspadai-agarIndonesia-tak-jadi-sasaran-pasar diakses tanggal 25 Mei 2015.

http://www.thefreedictionary.com/melanomata diakses tanggal 14 Agustus 2016. 